\title{
Comprehensive Evaluation on the Influence of Retailer's Characteristics on Online Purchasing Intention - a Thematic Review
}

\author{
G.P.H. Kandambi and W.M. J. I Wijayanayake \\ Rajarata University of Sri Lanka, Department of Business Management, Faculty of Management \\ Studies, Mihintale, Sri Lanka \\ University of Kelaniya, Department of Industrial Management, Faculty of Science, \\ Dalugama, Sri Lanka
}

Correspondence should be addressed to: G.P.H. Kandambi; kandambi@gmail.com

Received date: 21 February 2017; Accepted date: 24 Mai 2017; Published date: 19 December 2017

Academic Editor: Deepika Jhamb

Copyright (C 2017. G.P.H. Kandambi and W.M. J. I Wijayanayake . Distributed under Creative Commons CC-BY 4.0

\begin{abstract}
The way of transact between buyer and seller has been changed due to the development of Internet and socio economic activities. The interest of touring a bodily shop has been changed with the aid of on line purchasing and outlets can now effortlessly reach international markets from their local base, without the want for outlet space and warehousing. This makes market price penetrated. The vendor performs an essential role in online purchasing. This evaluation focuses on retailer's characteristics, which influence online purchasing. The assessment will lay the foundation to perceive the gap, as well as its scope for further research.

Thematic analytical approach was conducted to evaluate this study. The evaluation employs forty-three $(n=43)$ leading and peer-reviewed conferences and indexed journals between year 2010 and 2015. Ten $(n=10)$ sub themes were identified from the investigated variables based on their working definitions.

Moderating abilities of the product and price need to be explored, though they are critical factors of online purchasing. In the context of online shopping need to explore different product category separately, since virtual products and real product doesn't work together. Further studies need to focus more on retailer' characteristics and their antecedents, which are not clear. Future research should explore a wider range of variables with a comprehensive integrated model.
\end{abstract}

Keywords: Retailer Characteristics, Online Purchasing Intention, E-commerce.

Cite this Article as: G.P.H. Kandambi and W.M. J. I Wijayanayake (2017)," Comprehensive Evaluation on the Influence of Retailer's Characteristics on Online Purchasing Intention - a Thematic Review ", Journal of Internet and e-Business Studies, Vol. 2017 (2017), Article ID 997423, DOI:10.5171/2017.997423 


\section{Introduction}

With the high growth rate of internet services, online socio-economic activities have changed the way people transact. As a result, the act of visiting a physical store has been replaced by online shopping, especially in developed countries (Abiodun 2013). According to Rainer and Turban (2002) cited in Alfina et al. (2014), Ecommerce is defined as a transaction between two parties, the exchange of goods, services, or information, using the web service. E-commerce creates opportunities for all to sell online (Ling et al. 2010). The growth of e-commerce encouraged people to start online businesses (Meskaran et al. 2013).

Online shopping is popular in society because it has several advantages over traditional shopping (Alam \& Yasin 2010). Accordingly, the benefit of buyer, seller and society can be identified. The buyer can enjoy the global reach of the transactions, an extensive product and service selection, the flexibility of shopping anywhere at any time (Alam \& Yasin 2010), lower price (Jiang et al. 2013) and without worrying about parking spaces at the shop (Alam \& Yasin 2010). The seller can reach the global market easily while working locally and there is no requirement for outlet space and warehousing. Hence, sellers can offer competitive pricing on their products (Hajiha et al. 2014). Online shopping eliminates the need for travel, thus reducing traffic and environment pollution, which can be considered as a social benefit.

But, now people are reluctant to purchase online based on uncertainty and risk that they feel, though that has growing past years, (Alfina et al. 2014; Cha 2011; Meskaran et al. 2013; Nazir et al. 2012). Because of numerous issues of uncertainty, (Zhang et al. 2010), many online shoppers use the Internet only to search for product information, but do not make the purchase online (Kim \& Forsythe 2010). According to Chen et al. (2015), though online shopping is convenient and flexible, consumers often feel doubtful about the possible risks and benefits. That is happening due to difficulty in recognizing the other party engages with online in client server architecture (Alfina et al. 2014)

In essence, the consumers' behavior in online purchasing is very complex and personal (Chen et al. 2015). Further, factors causes to online shopping intention is still a matter, even the results from researches are loose, fragmented and disintegrated (Sahney et al. 2013). Hence the introduction of a comprehensive integrated model is a major requirement. Abu-shamaa \& Abu-Shanab (2015) argue that the online purchasing intention is affected by both technology and sociocultural factors, according to previous studies.

Accordingly, the attitudes and behaviors of consumers need to be examined and reexamined in the future (Cho \& Sagynov 2015). Though E-commerce has many opportunities, it also has various challenges (Khurana \& Mehra 2015). The number of online purchases is very poor when compared to other online activities in the world (Meskaran et al. 2013).

Consumer, retailer, website and macro environmental factors are the major components that impact the consumer's online purchase intention (Cheung et al., 2003). Of these, the retailer characteristics have an important role. According to Nazir et al. (2012), Chen \& Chen (2011), the retailer should offer a superior consumer service to attract the online consumer.

\section{Research Problem}

But, what factors lead a consumer to shop online is a matter that has suggested a lot of interest, although the results from research are loose, fragmented and disintegrated (Sahney et al., 2013) since consumer decisions are personal, and often very complex behaviors (Chen et al., 2015). Further comprehensive literature review cannot be found in the context of ecommerce with regard to retailer characteristics that influence online purchase intention. Hence, the question of which retailer characteristics influence the

G.P.H. Kandambi and W.M. J. I Wijayanayake (2017), Journal of Internet and e-Business Studies, DOI: $10.5171 / 2017.997423$ 
online purchasing intention is still a problem.

\section{Aims}

This study aims to identify the research gaps and all variables in the context of retailer characteristics which influence peoples' online purchasing intentions, through a thematic literature review. It also attempts to start work towards developing a comprehensive model to address the gaps identified by the evaluation, for future research.

\section{The Review Process}

\section{Design}

This paper employed a thematic analysis approach to identify, analyze and report data in articles collected. According to the process of thematic analysis, specified themes or areas were identified. Thematic analysis is a method for identifying, analyzing and reporting patterns (themes) within data (Braun \& Clarke, 2014). The researcher has his own right to customize a six step process aligned to the current research review (Braun \& Clarke, 2014).

\section{Search Method}

\section{Sample}

Research articles were collected from the ACM Digital Library (ACM), Emerald Journals (Emerald), and Google Scholar, Elsevier, Science Direct, IEEE, Tailors,
SEGE, and EBSCO data bases using key words: Factor influence to purchase online, online purchasing intention and Ecommerce. Indexed journals and conference proceedings articles were reviewed from the last five years (between 2010 and 2015).

\section{Inclusion/Exclusion criteria}

Research papers, primary research studies from Sri Lanka and from major regions in the world on the factors effecting online purchasing, published in English and between year 2010 - 2015, were the main inclusion criteria evaluated. And other than above were excluded from the result.

\section{Search outcome}

Three hundred and twenty eight $(n=328)$ articles have been identified in the evaluation, including indexed journals and conference proceedings. They were filtered for each condition (as shown in Figure 1). To determine the relevance of the articles, the principal author read each article. Hence one hundred and forty nine $(n=149)$ were rejected as not being directly relevant to the study while the balance one hundred and seventy nine $(n=179)$ were examined for more details. These were examined against the inclusion and exclusion criteria and one hundred and twenty two $(n=122)$ were identified for the quality appraisal. From the quality appraisal one hundred and twelve $(n=112)$ were selected for the thematic review. 


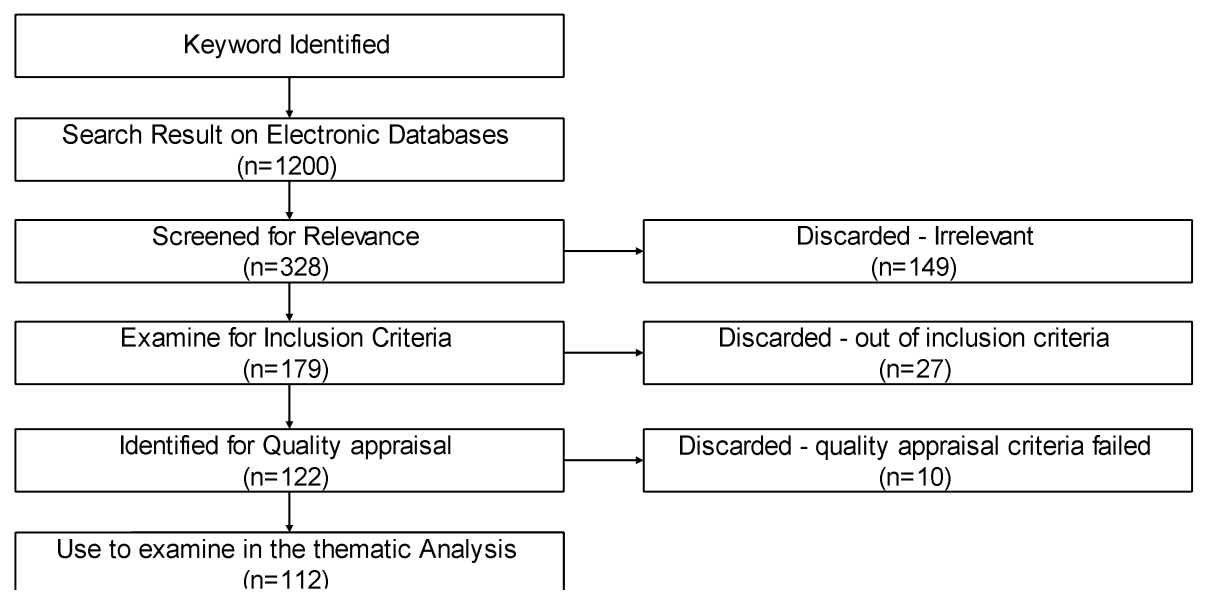

Fig. 1: Search Criteria Flow Chart

Source: Kandambi \& Wijenayaka (2017)

\section{Period of Study}

The thematic evaluation employs twelve $(n=12)$ articles from 2010, nineteen $(n=19)$ articles from 2011, eighteen $(n=18)$ articles from 2012, seventeen $(n=17)$ articles from 2013 , twenty four $(n=24)$ articles from 2014 and twenty one $(n=21)$ articles from 2015.

\section{Subject Area of the studies}

Of these studies, ninety four $(n=94)$ articles are from sixty four $(n=64)$ reputed journals and seventeen $(n=17)$ articles are from fifteen $(n=15)$ conference proceedings. The leading, peer-reviewed conferences and journals can be divided into three main categories: Management, Information Communication Technology and Applied Sciences. Accordingly, fourteen $(n=14)$ subject areas were addressed: Business Management, Economics and Finance, Marketing, Distribution Management and Business and Social Science which were the main subject areas in the Management category. Human computer interaction, Ecommerce, Management Information Systems, Computer Science and Information Systems, Internet and Networking and Applications group into the Information Communication Technology category. Finally, Applied Sciences, Industrial Management and
Engineering group under the Applied Science category.

\section{Data Abstraction and Synthesis}

The selected papers were read several time and words were highlighted while reading was done to extract major themes and sub themes, by the principle author. These were then grouped as far as possible.

\section{Analysis}

This evaluation consists of two main categories, including the independent variable and dependent variable. Retailer characteristics and their impact on the intention of the online purchaser were evaluated. The type of relationship and the impact effects of moderating variable and mediating effect on the relationship have been considered in this analysis.

Of the one hundred and twelve $(n=112)$ articles, forty three $(\mathrm{n}=43) \quad(38.39 \%)$ articles were contributed to address retailer characteristics. Fifty $(n=50)$ retailer related variables in different names were identified from those articles (As shown in Table 1.1). These variables were then categorized into ten $(n=10)$ sub themes based on their working definitions since identical variables existed. After sales service (subtheme 1.1), Price (subtheme 1.2), Customer Service (subtheme 1.3),

G.P.H. Kandambi and W.M. J. I Wijayanayake (2017), Journal of Internet and e-Business Studies, DOI: $10.5171 / 2017.997423$ 
Logistics (subtheme 1.4), Method of

Payment (subtheme 1.5), Product (subtheme 1.6), Promotion (subtheme 1.7),
Reputation (subtheme 1.8), Social presence (subtheme 1.9), Third party security (subtheme 1.10).

Table 1: Theme Classification Evidence

\begin{tabular}{|l|c|l|}
\hline Theme & Article & Variable \\
\hline Theme 1 & 43 & 50 \\
\hline Theme 2 & 26 & 15 \\
\hline
\end{tabular}

Table 2: Variable Grouping under Subthemes

\begin{tabular}{|c|c|c|}
\hline \multicolumn{3}{|c|}{ Independent Variable - Theme 1} \\
\hline ST1.1 & After sales service & $\begin{array}{l}\text { Guarantees, Return Policy, E-scape and Responsiveness, } \\
\text { Guaranteed Return Policy }\end{array}$ \\
\hline ST1.2 & Price & Cost, Perceived Price, Price Consciousness, \\
\hline ST1.3 & Customer Service & $\begin{array}{l}\text { Communication, Customer Service, E-commerce service } \\
\text { quality, E-service, E-Service quality, Online Communication, } \\
\text { Service Quality, Web Service Quality, Website Customer } \\
\text { Service, Website Service Quality, Perceived Expertise in } \\
\text { Order Fulfillment, Service Excellence Motivation }\end{array}$ \\
\hline ST1.4 & Logistics & Delivery, Delivery Efficiency, Delivery Quality, Logistics \\
\hline ST1.5 & Method of Payment & Payment, Payment Method \\
\hline ST1.6 & Product & $\begin{array}{l}\text { Lower Price, Merchandising, Product Quality, Product Type, } \\
\text { Sales Price, Wider selection, Product Category, Product } \\
\text { Motivation, }\end{array}$ \\
\hline ST1.7 & Promotion & Price Discount, Promotion \\
\hline ST1.8 & Reputation & $\begin{array}{l}\text { Benevolence, Brand Reputation, Cooperate Credibility, E- } \\
\text { tailor Reputation, Fear of Reputation Damage, Reputation, } \\
\text { Vendor Reputation, Vendor Quality, Website Brand, } \\
\text { Cognitive Trust, Calculation Base Cognitions, Perceived } \\
\text { Reputation }\end{array}$ \\
\hline ST1.9 & Social presence & Social Presence \\
\hline ST1.10 & Third party security & $\begin{array}{l}\text { Third Party Payment Platform, Trust in third party } \\
\text { assurance }\end{array}$ \\
\hline \multicolumn{3}{|c|}{ Dependent Variable - Theme 2} \\
\hline ST2.1 & Purchase Intention & $\begin{array}{l}\text { Behavioral Intention, Buying intention, Consumer intention } \\
\text { to shop online, Consumer intention to purchase online, } \\
\text { Intention, Intention to Purchase, Intention to Use, Online } \\
\text { Purchase, Online Purchase Intention, Online Shopping, } \\
\text { Online Shopping Behavior, Purchase, Purchase Intention }\end{array}$ \\
\hline ST2.2 & Re-purchase Intention & Continuance Intention, Online Repurchase Intention, \\
\hline
\end{tabular}

ST: Subtheme

G.P.H. Kandambi and W.M. J. I Wijayanayake (2017), Journal of Internet and e-Business Studies, DOI: $10.5171 / 2017.997423$ 


\section{Independent variable investigation (Theme 1)}

Ten $(n=10)$ retailer characteristics were found which influence online purchasing intention from forty three articles $(n=43)$. Further, the number of variables per each article and the total number of articles for particular variables were calculated to identify the impotency of the variables. Variable Reputation ( $\mathrm{n}=17 \mathrm{p}=38.6 \%)$ is the most frequently used variable among the studies and customer service $(n=16$ $\mathrm{p}=36.4 \%)$, product $(\mathrm{n}=11 \mathrm{p}=25 \%)$, promotion $(n=5 \mathrm{p}=11.4 \%)$ took the above level of $10 \%$ frequency. Other variables have below 10\% frequency. (As shown in Table 1.3.)

However, maximum number of retailer characteristics use as independent variable at a study is five $(n=5)$ by study of Bauman 2015 and Aghdaie et al. 2011. Another one $(n=1)$ study used four $(n=4)$ retailer characteristics as independent variables. Accordingly two $(\mathrm{n}=2)$ studies used three $(n=3)$ variables, nine $(n=9)$ studies used two $(n=2)$ variables and twenty nine $(n=29)$ studies used only one $(n=1)$ retailer characteristic as an independent variable.

Table 3: Retailer Characteristic Evaluation Grid

\begin{tabular}{|c|c|c|c|c|c|c|c|c|c|c|c|}
\hline Researcher & 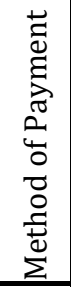 & 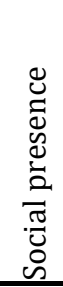 & 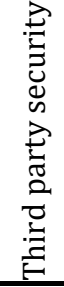 & $\stackrel{\Xi}{\Xi}$ & 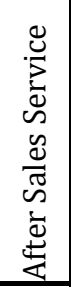 & 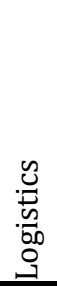 & 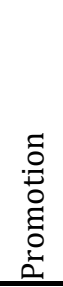 & $\begin{array}{l}\tilde{U} \\
\underline{Z} \\
0 \\
0\end{array}$ & 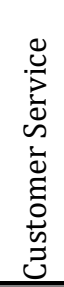 & 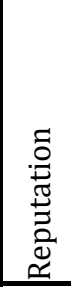 & $\begin{array}{l}\frac{0}{d} \\
\frac{\pi}{\pi} \\
\frac{\pi}{\pi} \\
\frac{0}{2} \\
0\end{array}$ \\
\hline (Lin \& Sun 2009) & & & & & & & & & $\bar{a}$ & & 1 \\
\hline (Kim et al. 2010) & & & & & & & $\bar{a}$ & & & & 1 \\
\hline (Kim et al. 2012) & & & & a & & & & & & & 1 \\
\hline (He \& Bai 2011) & & & & & & & & & $\mathrm{a}$ & & 1 \\
\hline (Zhang et al. 2011) & & & & & & & & & $\mathrm{a}$ & & 1 \\
\hline (Zhang \& Liu 2011) & & & & & & & & & $\mathrm{a}$ & & 1 \\
\hline (Bianchi \& Andrews 2012) & & & $\mathrm{a}$ & & & & & & & & 1 \\
\hline (Bente et al. 2012) & & & & & & & & & & $\mathrm{a}$ & 1 \\
\hline (Javadi et al. 2012) & & & & & $\bar{a}$ & & & & & & 1 \\
\hline (Kim \& Lennon 2013) & & & & & & & & & & $\bar{a}$ & 1 \\
\hline (Mohmed et al. 2013) & & $\mathrm{a}$ & & & & & & & & & 1 \\
\hline (Thamizhvanan \& Xavier 2013) & & & & & & & & & & $\mathrm{a}$ & 1 \\
\hline (Sahney et al. 2013) & & & & & $\overline{\mathrm{a}}$ & & & & & & 1 \\
\hline (Alfina et al. 2014) & & & & & & & & & & $\mathrm{a}$ & 1 \\
\hline (Chang et al. 2014) & & & & & & & & & & $\mathrm{a}$ & 1 \\
\hline (Eun Lee \& Stoel 2014) & & & & & & & $\mathrm{a}$ & & & & 1 \\
\hline (Bo et al. 2014) & & & & & & & & $\mathrm{a}$ & & & 1 \\
\hline (Shadkam et al. 2014) & & & & & & & & & & $\bar{a}$ & 1 \\
\hline (Sahney et al. 2014) & & & & $\mathrm{a}$ & & & $\mathrm{a}$ & & & & 2 \\
\hline
\end{tabular}

G.P.H. Kandambi and W.M. J. I Wijayanayake (2017), Journal of Internet and e-Business Studies, 


\begin{tabular}{|c|c|c|c|c|c|c|c|c|c|c|c|}
\hline (Vos et al. 2014) & & & & & $\sqrt{a}$ & & & & & & 1 \\
\hline (Abu-shamaa \& Abu-Shanab & $\bar{a}$ & & & & & & & & & & 1 \\
\hline (Hille et al. 2015) & & & & & & & & & & $\bar{a}$ & 1 \\
\hline (Shihyu et al. 2015) & & & & & & $\bar{a}$ & & & & & 1 \\
\hline (Ariff et al. 2013) & & & & & & & & & $\mathrm{a}$ & & 1 \\
\hline (Alam \& Yasin 2010) & & & & & & & & & & a & 1 \\
\hline (Featherman et al. 2010) & & & & & & & & & $\mathrm{a}$ & $\mathrm{a}$ & 2 \\
\hline (Zhang et al. 2010) & & & & & & & & & 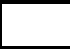 & $\bar{a}$ & 1 \\
\hline (Chen \& Chen 2011) & & & & & & & & $\mathrm{a}$ & $\mathrm{a}$ & & 2 \\
\hline (Delafrooz et al. 2011) & & & & $\bar{a}$ & & & & $\mathrm{a}$ & $\mathrm{a}$ & & 3 \\
\hline (Boyu 2012) & & & & & & & $\bar{a}$ & $\mathrm{a}$ & - & & 2 \\
\hline (Ranjbarian et al. 2012) & & & & & & & & $\bar{a}$ & $\bar{a}$ & & 2 \\
\hline (Tang \& Nguyen 2013) & & & & & & & & & $\mathrm{a}$ & & 1 \\
\hline (Hsu et al. 2014) & & & & & & & & & 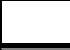 & $\mathrm{a}$ & 1 \\
\hline (Cho \& Sagynov 2015) & & & & & & & & $\mathrm{a}$ & $\mathrm{a}$ & & 2 \\
\hline (Sobihah et al. 2015) & & & & & & & & & $\mathrm{a}$ & & 1 \\
\hline (Naovarat \& Juntongjin 2015) & & & & & & $\bar{a}$ & & & $\mathrm{a}$ & & 2 \\
\hline (Tamimi \& Sebastianelli 2015) & & & & & & & & $\bar{a}$ & 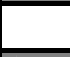 & $\mathrm{a}$ & 2 \\
\hline (Sharma \& Lijuan 2015) & & & & & & & & & $\mathrm{a}$ & & 1 \\
\hline (Shan et al. 2010) & & & $\overline{\mathrm{a}}$ & & & & & $\bar{a}$ & & $\bar{a}$ & 3 \\
\hline (Zhang et al. 2012) & & & & & & & & $\mathrm{a}$ & & $\mathrm{a}$ & 2 \\
\hline (Tabatabayi et al. 2012) & & & & & & $\bar{a}$ & & $\mathrm{a}$ & $\bar{a}$ & $\mathrm{a}$ & 4 \\
\hline (Aghdaie et al. 2011) & $\mathrm{a}$ & & a & & & $\mathrm{a}$ & $\mathrm{a}$ & 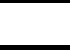 & & $\mathrm{a}$ & 5 \\
\hline (Bauman 2015) & & $\overline{\mathrm{a}}$ & & & $\overline{\mathrm{a}}$ & & & $\mathrm{a}$ & $\mathrm{a}$ & a & 5 \\
\hline \# of research per variable & 2 & 2 & 3 & 3 & 4 & 4 & 5 & 11 & 16 & 17 & \\
\hline$\%$ & $\stackrel{10}{\not}$ & $\stackrel{\text { Ln }}{+2}$ & $\begin{array}{l}\infty \\
\dot{0}\end{array}$ & 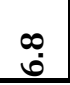 & $a$ & $a$ & $\stackrel{+}{ت}$ & 노 & $\begin{array}{l}+ \\
\text { চे } \\
\text {. }\end{array}$ & $\begin{array}{l}0 \\
\infty \\
\infty \\
m\end{array}$ & \\
\hline
\end{tabular}

\section{After Sales Service}

After sales service is a very sensitive matter and has to be carefully managed. Careful attention has to be paid to complaints by fast answering and friendly when refunding or changing and handling of complaint should be fast and the delivery should be quick. (Ruimei et al. 2012). Retailers must invest more to train their staff to handle and negotiate such sensitive situations (Ruimei et al. 2012). It is the retailer's responsibility to pay careful attention to delivery processes and the returning of goods (Jiang et al. 2013). A guarantees is an antecedent of aftersales service which includes good guarantees, return policies and after-sales assistance used to measure trust in online shopping (Bauman 2015).

\section{Price}

Price is totally different from value and these are two behavioral intentions (Liang et al. 2015). The consumer's online purchasing decision is very sensitive to price, which is a very common factor (Delafrooz et al. 2011). Hence, the retailer can attract the online consumer by providing competitive pricing for the product and thus motivate them to purchase online (Delafrooz et al. 2011). However, online prices are lower when compared to prices in physical stores (Nazir et al. 2012; Cho \& Sagynov 2015). A reason for that is the competition among the sellers within the marketplace (Hong 2015; Chen \& Chen 2011). Hence, this reveals that price competition is an important factor in the online context (Ozen \& Engizek 2014) and price has

G.P.H. Kandambi and W.M. J. I Wijayanayake (2017), Journal of Internet and e-Business Studies, DOI: $10.5171 / 2017.997423$ 
become one of the trusted measurement in the online context (Bauman 2015).

\section{Customer Service}

Customer service has a vital role in online purchasing to encourage people to purchase online (Delafrooz et al. 2011). Further, Hill et al. (2013) state that providing a creative e-service which Youngers can purchase by themselves is beneficiary. Hence, shoppers online purchase intention can be enhanced by a superior customer service providing the necessary inbound and outbound logistical delivery information to the consumer (Choon Ling et al. 2011). Further, responsiveness to a consumer complaint is mandatory, because responsiveness is highly important and should be timely and active (He \& Bai 2011). Accordingly, Kim \& Lennon (2013) propose to incorporate extended and enriched consumer services to reduce consumer risk while building the reputation and reliability of the company. Consumer service can be divided into two: before sale and after sale.

Service quality is one of the antecedents in customer service, which has strong associations with behavioral intention (He \& Bai 2011). The effective way to a high quality relationship with the online consumer is a high quality service (Sharma \& Lijuan 2015). According to Sobihah et al. (2015), perceived user interface quality, perceived product or service information quality, the notion of security risk and the notion of privacy are the factors influencing E-commerce service quality. But according to $\mathrm{He} \&$ Bai (2011), reliability and assurance were the most important antecedents among the service quality factors.

The convenience of the online consumer service is associated with the behavioral intention of purchasing (Jiang et al. 2013). New features and inventions introduced for a convenient service have increased customer expectations of convenience (Jiang et al. 2013). Ordering products, including the failure of on-time delivery, the uncertainty of waiting time for delivery, the risk of incomplete orders, damaged goods, unfriendly attitudes of the delivery person, and difficulty in returning unwanted products are some of the inconveniences faced by consumers (Jiang et al. 2013).

\section{Logistics}

Successful achievement in e-commerce depends on Logistical service quality and communications with the consumer about the delivery (Naovarat \& Juntongjin 2015; Javadi et al. 2012). But that has become the most crucial challenge faced by ecommerce companies (Reddy \& Divekar 2014). As a result, most e-commerce companies use their own delivery network to deliver goods (Reddy \& Divekar 2014). Further assurance of delivery time is an essential factor for customer satisfaction (Chou et al. 2015).

\section{Method of payment}

Consumer perceptions of online shopping convenience are inspiring simple and flexible payment methods provided by retailers (Jiang et al. 2013). Hence that convention is leading to enhance consumer's online shopping intention (Boyu 2012). One of the measurements of convenience is payment speed, which depends on transaction design and Internet connection functions (Jiang et al. 2013). The online consumer may abandon or never meet that seller again if there is a delay in the online payment (Jiang et al. 2013). But Abu-shamaa \& Abu-Shanab (2015) argue that none of the relationships are affected by the online payment method and this does not work as moderator. This is a contradictory situation that needs to be resolved in future research.

However, the online payment method has become a critical hurdle, directly affecting online purchasing (Gong et al. 2013). Hence e-vendors try to promote diverse payment methods to acquire online consumers (Chen \& Chou 2012).

Hence, cash on delivery and/or credit or debit card are common online payment methods in the business world (Chen \& Chou 2012). The consumer often prefers the cash on delivery method, which is risk free and the payment is made upfront after 
obtaining the good or service (Chen \& Chou 2012; Abu-shamaa \& Abu-Shanab 2015). Accordingly, Gong et al. (2012) proposed engaging with reliable logistics service providers who can deliver the product and collect cash from the consumer. But when comparing the consumers who are willing to pay by credit cards or cash, they have a different trust level (Abu-shamaa \& AbuShanab 2015). However, the use of secured payment gateways, money back guarantees and real time order validation and product tracking can reduce the fear of online payment (Reddy \& Divekar 2014).

\section{Product}

Consumer online shopping demand is highly sensitive to product factor by significant positive correlation (Boyu 2012). Product appearance style, product quality, unique product features and low price are antecedents of the product factor (Boyu 2012). Further, it is very important to offer product reviewing options and product information which measure online trust (Bauman 2015). Accordingly, consumer perceived ease of use is enhanced by product quality (Cho \& Sagynov 2015) and quality has a direct impact on purchase intention (Ling et al. 2010).

Various types of associations can be seen in the context of online purchasing. But most relationships hold result subject to the product type or product category (Cha 2011; Bo et al. 2014). The online purchase intention may vary according to the different product types (Keisidou et al. 2011). Accordingly, Kim et al. (2010) argue that perceived informativeness and purchasing entertainment also depend on the product type involved. Even price, perceived usefulness, ease of use, enjoyment, security, social norm, flow, and gender can vary depending on whether it is a virtual or real item (Cha 2011). Further, different antecedents of the risk perception were influenced by the different product categories (Bo et al. 2014). Hence, risk can vary based on the product type purchased. Further, attitudes towards online shopping are affected by product type (Keisidou et al. 2011). Depending on whether the product is inexpensive or expensive, a short-term product or a long-term product (Keisidou et al. 2011). When evaluating the literature it can be concluded that product involvement is very high and it works as a significant moderator (Kim et al. 2010).

\section{Promotion}

Online purchasing intention statistically stimulates by promotion factor (Boyu 2012). Sales discounts or price discounts as the main promotion strategy make purchasing impulsive (Eun Lee \& Stoel 2014; Ozen \& Engizek 2014). But it should be very careful when choosing the price discount size, which creates skepticism in the consumer's mind (Eun Lee \& Stoel 2014). Too large a discount from unfamiliar online retailers may create doubt in the consumer's mind (Eun Lee \& Stoel 2014). Hence to reduce that uncertainty, the retailer must select the appropriate price discount, and guarantee free shipping and free return services to the consumer (Eun Lee \& Stoel 2014).

\section{Reputation}

Reputation and trust are not two words; reputation is a significant element in trust (Bauman 2015; Alam \& Yasin 2010). Reputation creates a trusted environment in online purchasing, which trusted, and assured the consumer has more intention to buy online (Shadkam et al. 2014; Bente et al. 2012). Hence, it can be said that benevolence also has a significant positive impact on online purchasing intention (Chen 2012).

Online retailers should incorporate online features that build a reputation of a reliable company (Kim \& Lennon 2013). Perceived reputation has an indirect influence on trust through perceived security (Ruimei et al. 2012). Reputation became one of the most influencing factors towards perception of the web site quality (Kim \& Lennon 2013). Hence, it is required to make the company name popular and familiar through various promotional activities (Kim \& Lennon 2013). Further, 
the credibility of the brand became one of the main factors that build reputation as well (Sahney et al. 2013). Good credibility will reduce the impact of perceived privacy risk and/or reduce its impact on user intentions (Featherman et al. 2010).

"Firm reputation has been deemed important since it cannot be easily created or traded within a short time; however, its importance is even more critical in the online retailing context since consumers have fewer signals than they have from physical stores". (Jin et al., 2009 cited in Kim \& Lennon 2013)

Hence, online retailers need to pay careful attention to inculcate and build reputation and to make that reputation a source of sustainable competitive advantage (Kim \& Lennon 2013). Reputation can contribute to reducing perceived risk and eliciting positive emotion, which eventually leads to the purchase intention (Kim \& Lennon 2013).

Brand orientation has significant association with customer online purchase intention (Ling et al. 2010). Hence, it is mandatory to reform and improve ebranding strategies to attract more online consumers (Chang et al. 2014). Trust and brand has tight association between them. Well-established brands have high trust building capability (Cho \& Sagynov 2015). Also web site quality and web site brand can build consumer trust (Chang et al. 2014). Such trust can also be built by displaying brand promotion information through the company logo (Sahney et al. 2013). Hence, credibility of the brand becomes one of the main factors that build reputation as well (Sahney et al. 2013).

\section{Social Presence}

According to Kehrwald \& Bejamin (2008), Social presence defines the way people relate to each other and communicate effectively in different ways. For example, the highest degree of social presence can be identified between retailer and consumer when they are face-to-face. Weakest and lowest level of social presence can be identified whereas text-based communication is exist (Mohmed et al. 2013). Hence, Mohmed et al. (2013) argue that the social presence in e-commerce is at a moderate level. That level of social presence can be enhanced by using live chat (Kaur \& Madan 2014) and physical presence (Bauman 2015). The study of Mohmed et al. (2013) found that social presence positively influences online instruction through enhancement of social networks in e-commerce as well as intention to purchase online (Mohmed et al. 2013)

\section{Third party Security}

Third party assurances have been identified as one of the most influencing factors in online purchase intention and it was positive and very strong influence (Bianchi \& Andrews 2012). Hence, third party trust marks use to build the trust of online stores (Cho \& Sagynov 2015). Further, online shoppers believe that they can earn confidence which leads to greater sales revenues through collaboration with reputable third party payment companies (Gong et al. 2012). Hence, practitioners or the retailers should ensure that certification of the third party assurances is displayed very clearly and is easy to recognize (Bianchi \& Andrews 2012). Third-party payment platforms should focus more on reducing transactional risk (Yang et al. 2015).

\section{Dependent variable investigation (Theme 2)}

\section{Online purchasing behavior}

Sahney et al. (2013) define onlinepurchasing behavior as the degree to which consumers access, browse, shop and transact and repeat the behavior. Online retailers frequently struggle to attract new customers to their web sites and retain existing ones (Mohamed et al. 2014). Hence, it is very critical to determine what factors cause consumers to purchase online (Kim \& Lennon 2013). In some research, the online shopping process is identified as two separate processes - the psychological and behavioral process, which influence 
each other (Yang et al. 2011). Therefore, online retailers need to recognize and address the psychological aspect (Mohamed et al. 2014) and behavioral aspect of online customers separately (Yakup \& Jablonsk 2012; Sahney et al. 2014).

\section{Online purchasing intention}

The consumer's intention to buy online, is defined as the likelihood that a consumer plans to buy online in the near future (Chen 2012; Shadkam et al. 2014). In general, purchase intention can be measured as the extent to which a consumer is likely to make purchases at present and in the future (Hong 2015). Other researchers have measured purchase intention as the preference for an online merchant on a continuum between a digital storefront and an e-market place (Hong 2015). However, it can be defined as a future plan to purchase online. Online purchasing behavior is manipulated by different factors, which influence the intention to purchase online (Mohmed et al. 2013).

The retailer plays a critical role in this context. Accordingly, guaranteed return policies, and the perceived image of the web site can be identified as some areas to build an assurance and trustful mindset in the consumer (Sahney et al. 2013). In addition, vendor reputation and vendor system assurance make an assured and trustful customer for online the context (Shadkam et al. 2014). Further, the method of payment by using credit card and debit card information makes a strong impact on the online purchasing intention (Aghdaie et al. 2011). Also, promotion (Aghdaie et al. 2011; Boyu 2012), product (Boyu 2012) and price (Chen \& Chen 2011; Nazir et al. 2012) are a few other influencing factors that affect the online purchasing intention. However, it can be seen that third party assurances have the strongest predicting power of online purchase intention (Bianchi \& Andrews 2012).

\section{Discussion}

Online shopping context has a large number of variables which influence purchasing intention (Javadi et al. 2012). Various types of research have been done to study this complex context with many limitations. With the many limitations, some of the research explores a few sets of variables at a time (Javadi et al. 2012; Kim et al. 2010; Ozen \& Engizek 2014). Still there are many areas to be investigated due to the limitation of knowledge of the online shopping context (Cha 2011). Hence further study is required, with a broader and more comprehensive research model to identify those other factors and lapses (Kim et al. 2010; Adnan 2014; Tamimi \& Sebastianelli 2015; Javadi et al. 2012; Ozen \& Engizek 2014; He \& Bai 2011).

Future studies on online purchasing intention should focus strongly on product characteristics and the merchant's characteristics to enhance power of the proposed model (Gong et al. 2013). The retailer must be aware of the best suited logistic mechanism, payment systems and other factors to gain a competitive advantage (Gong et al. 2012).

Product type is one of the main characteristics in the retailer, which has a great influence in the context of online purchasing. Hence it is required to confirm these findings for different product types in future research (Eun Lee \& Stoel 2014). The consumer's level of trust varies according to the product type (Chen \& Chou 2012). Further, the product type influences several relationships as a moderator (Chen \& Chou 2012). When exploring the factors effecting online purchase intention we should focus on each product category separately such as a virtual and real item (Cha 2011). They do not work together. Even for the purpose of generalization of the result, digital product and non-digital product should be re-tested separately (Bo et al. 2014). It should be careful when using two products with fictitious brands for an experimental survey, which may reduce the generalizability of the result to other products (Eun Lee \& Stoel 2014).

Consumer judgment of product quality and the credibility of retailer totally depends on whether the original price, dollar or

G.P.H. Kandambi and W.M. J. I Wijayanayake (2017), Journal of Internet and e-Business Studies, DOI: $10.5171 / 2017.997423$ 
percentage amount of price discounts or if the selling price is unknown (Eun Lee \& Stoel 2014). Further, even its level of impact on purchasing decision and impact from discount size is unknown (Eun Lee \& Stoel 2014). Even the consumer level of trust varies according to the product price (Chen \& Chou 2012). Price also has a moderating effect on all other relationships (Chen \& Chou 2012).

According to the argument made by He \& Bai (2011), there are several other factors which need to be investigated which affect customer service quality. Further, Sharma \& Lijuan (2015) propose to investigate the relationship between perceived online service quality and user satisfaction toward purchasing behaviors. Mohmed et al. (2013) suggested evaluating the impact from usability of e-commerce, information quality, and payment security towards intention to purchase. Hence, He \& Bai (2011) show the necessity of empirical research with enlarged coverage and add some variables, which focus on online industry.

\section{Conclusion}

Product type and the price of product play a critical role in the context of the retailer's characteristics towards online purchasing. Hence, it is required to investigate the impact from product type and price to other factors and its moderating capability. When exploring the factors affecting online purchase intention, we must focus on each product category separately (virtual item/ real item) and these do not work together. More retailer's characteristics need to be included to enlarge and complete the research model. It is a major requirement of future research to explore a wider range of variables with a comprehensive integrated model. Further studies need to focus more on retailer's characteristics and antecedents, which are not clear.

\section{Reference}

1. Abu-Shamaa, R. \& Abu-Shanab, E., 2015. Factors influencing the intention to buy from online stores: An empirical study in Jordan. In 2015 IEEE 8th GCC Conference and Exhibition, GCCCE 2015. Muscat, pp. 14.

2. Aghdaie, S.F.A., Piraman, A. \& Fathi, S., 2011. An Analysis of Factors Affecting the Consumer' s Attitude of Trust and their Impact on Internet Purchasing Behavior Department of Management. nternational Journal of Business and Social Science, 2(23), pp.147-158.

3. Alam, S.S. \& Yasin, N.M., 2010. What factors influence online brand trust: Evidence from online tickets buyers in Malaysia. Journal of Theoretical and Applied Electronic Commerce Research, 5(3), pp.78-89.

4. Alfina, I. et al., 2014. The impact of cognitive trust and e-wom on purchase intention in C2C e-commerce site. Journal of Computer Science, 10(12), pp.25182524.

5. Ariff, M.S.M. et al., 2013. Web-based Factors Affecting Online Purchasing Behaviour. In IOP Conference Series: Materials Science and Engineering. p. 12038 .

6. Bente, G., Baptist, O. \& Leuschner, H., 2012. To buy or not to buy: Influence of seller photos and reputation on buyer trust and purchase behavior. International Journal of Human Computer Studies, 70(1), pp.1-13.

7. Bianchi, C. \& Andrews, L., 2012. Risk, trust, and consumer online purchasing behaviour: a Chilean perspective. International Marketing Review, 29(3), pp.253-275.

8. Boyu, K., 2012. The empirical study of motivators for online shopping demand based on behavior analysis. In Proceedings of the 2012 2nd International Conference on Business Computing and Global Informatization, BCGIN 2012. pp. 225-228.

9. Chang, K.-C. et al., 2014. The Impact of Website Quality and Perceived Trust on Customer Purchase Intention in the Hotel Sector: Website Brand and Perceived Value as Moderators. International Journal of

G.P.H. Kandambi and W.M. J. I Wijayanayake (2017), Journal of Internet and e-Business Studies, DOI: $10.5171 / 2017.997423$ 
Innovation, Management and Technology, 5(4), pp.255-260.

10.Chen, S.F. \& Chen, C.-Y., 2011. Influencing Factors on Price Tolerance of Internet Customers. Journal of International Management Studies, 6(2), pp.1-12.

11.Chen, Y.-T. \& Chou, T.-Y., 2012. Exploring the continuance intentions of consumers for B2C online shopping: Perspectives of fairness and trust. Online Information Review, 36(1), pp.104-125. 12.Cheung, C. M. K., Zhu, L., Kwong, T., Chan, G. W. W. and Limayem, M. (2003) 'Online Consumer Behavior: A Review and Agenda for Future Research', BLED 2003 Proceedings, pp. 194-218.

13.Chou, S., Chen, C.-W. \& Lin, J.-Y., 2015. Female online shoppers: Examining the mediating roles of e-satisfaction and etrust on e-loyalty development. Internet Research, 25(4), pp.542-561.

14.Dai, Bo, Forsythe, S., Kwon, W., 2007. The Impact of Online Shopping Experience on Risk Perceptions and Online Purchase Intentions: The Moderating Role of Product Category and Gender. Journal of Electronic Commerce Research, 15(1), pp.13-24.

15.Delafrooz, N., Paim, L. \& Khatibi, A., 2011. Understanding Consumer's Internet Purchase Intention in Malaysia. African Journal of Business Management, 5(3), pp.2837-2846.

16.Kandambi G.P.H. and W.M. Janaka I Wijayanayake (2017), " Comprehensive Factor Evaluation on Impact of Consumer's Characteristic on Online Purchasing Intention in E- Commerce: A Literature Review", Journal of Internet and e-Business Studies, Vol. 2017 (2017), Article ID 757236, DOI: $10.5171 / 2017.757236$

17.Eun Lee, J. \& Stoel, L., 2014. High versus low online price discounts: effects on customers' perception of risks. Journal of Product \& Brand Management, 23(6), pp.401-412.

18.Featherman, M.S., Miyazaki, A.D. \&
Sprott, D.E., 2010. Reducing online privacy risk to facilitate e-service adoption: the influence of perceived ease of use and corporate credibility. Journal of Services Marketing, 24(3), pp.219-229.

19.Gajendra Sharma \& Wang, L., 2015. The effects of online service quality of ecommerce websites on user satisfaction. The Electronic Library, 33(3), pp.468-485.

20.G.P.H. Kandambi and W.M. Janaka I Wijayanayake (2017), " Comprehensive Factor Evaluation on Impact of Consumer's Characteristic on Online Purchasing Intention in E- Commerce: A Literature Review", Journal of Internet and e-Business Studies, Vol. 2017 (2017), Article ID 757236, DOI: $10.5171 / 2017.757236$

21.He, J. \& Bai, Y., 2011. Assessing the Relationship among Service Quality, Customer Satisfaction and Behavioral Intentions in Online Shopping Environments. In 2011 Fourth International Conference on Business Intelligence and Financial Engineering. pp. 155-159.

22.Hille, P., Walsh, G. \& Cleveland, M., 2015. Consumer fear of online identity theft: Scale development and validation. Journal of Interactive Marketing, 30, pp.1-19.

23.Hsu, M.-H., Chuang, L.-W. \& Hsu, C.-S., 2014. Understanding online shopping intention: the roles of four types of trust and their antecedents. Internet Research, 24(3), pp.332-352.

24.Javadi, M.H.M. et al., 2012. An Analysis of Factors Affecting on Online Shopping Behavior of Consumers. International Journal of Marketing Studies, 4(5), pp.8198.

25.Karahanna, E., 2003. Gefen et aIJTrust and TAM in Online Shopping. MIS Quarterly, 27(1), pp.51-90.

26.Kim, J. \& Lennon, S.J., 2013. Effects of reputation and website quality on online consumers' emotion, perceived risk and purchase intention: Based on the stimulusorganism-response model. Journal of

G.P.H. Kandambi and W.M. J. I Wijayanayake (2017), Journal of Internet and e-Business Studies, DOI: $10.5171 / 2017.997423$ 
Research in Interactive Marketing, 7(1), pp.33-56.

27.Kim, J.U., Kim, W.J. \& Park, S.C., 2010. Consumer perceptions on web advertisements and motivation factors to purchase in the online shopping. Computers in Human Behavior, 26(5), pp.1208-1222.

28.Lin, G.T.R. \& Sun, C.-C., 2009. Factors influencing satisfaction and loyalty in online shopping: an integrated model. Online Information Review, 33(3), pp.458475.

29.Mohmed, S.I., Azizan, B. \& Jali, Z., 2013. The Impact of Trust and Past Experience on Intention to Purchase in E-Commerce. International Journal of Engineering Research and Development, 7(10), pp.2835 .

30.Naovarat, S. \& Juntongjin, P., 2015. Factor that affecting success of EMarketplace in Thailand. In International Conference on Computer Science and Information Systems (ICCSIS-15). Pattaya: International Conference on Computer Science and Information Systems (ICCSIS15), pp. 15-18.

31.Ranjbarian, B., Fathi, S. \& Rezaei, Z., 2012. Factors Influencing on Customers' ESatisfaction: A case Study from Iran. Interdisciplinary Journal of Contemporary Research in Business, 3(9), pp.1496-1511.

32.Sahney, S., Ghosh, K. \& Shrivastava, A., 2013a. "Buyer's motivation" for online buying: an empirical case of railway eticketing in Indian context. Journal of Asia Business Studies, 8(1), pp.43-64.

33.Sahney, S., Ghosh, K. \& Shrivastava, A., 2013b. Conceptualizing consumer "trust" in online buying behaviour: an empirical inquiry and model development in Indian context. Journal of Asia Business Studies, 7(3), pp.278-298.

34.Shadkam, M. et al., 2014. Antecedents of Consumers' Intention to Shop online. Australian Journal of Basic and Applied
Sciences, 7(13), pp.190-197.

35.Shan, S., Hua, F. \& Zeng, Q., 2010. B2C ecommerce consumer decision-making model based on perceived benefit and perceived risk. In Proceedings of the International Conference on E-Business and E-Government, ICEE 2010. pp. 22222225.

36.Slater, P., 1965. The use of the repertory grid technique in the individual case. The British journal of psychiatry : the journal of mental science, 111(479), pp.965-975.

37.Sobihah, M. et al., 2015. E-Commerce Service Quality on Customer Satisfaction, Belief and Loyalty: A Proposal. Mediterranean Journal of Social Sciences, 6(2), pp.260-266.

38.Soto-Acosta, P. et al., 2014. The effect of information overload and disorganisation on intention to purchase online. Online Information Review, 38(4), pp.543-561.

39.Tabatabayi, F. et al., 2012. Simulating Online Consumer Satisfaction Using Fuzzy Cognitive Mapping. In 2012 Ninth International Conference on Information Technology - New Generations. pp. 540547.

40.Tamimi, N. \& Sebastianelli, R., 2015. The relative importance of e-tailer website attributes on the likelihood of online purchase. Internet Research, 25(2), pp.169-183.

41.Thamizhvanan, A. \& Xavier, M.J., 2013. Determinants of customers' online purchase intention: an empirical study in India. Journal of Indian Business Research, 5(1), pp.17-32.

42.Vos, A. et al., 2014. Electronic service quality in online shopping and risk reduction strategies. Journal of Systems and Inforation Technologym, 16(3), pp.170-186.

43.Yoon, C.C. \& Sagnov, E., 2015. Exploring factors that affect usefulness, ease of use, trust, and purchase intention in the online

G.P.H. Kandambi and W.M. J. I Wijayanayake (2017), Journal of Internet and e-Business Studies, DOI: $10.5171 / 2017.997423$ 
environment. International Journal of Management \& Information Systems, 19(1), pp.21-36.

44.Zhang, G. \& Liu, Z., 2011. Effects of influential factors on consumer perceptions of uncertainty for online shopping. Nankai Business Review International, 2(2), pp.158-171.

45.Zhang, K.Z.K. et al., 2010. Exploring the moderating effect of information inconsistency in a trust-based online shopping model. In Proceedings of the Annual Hawaii International Conference on
System Sciences. pp. 1-9.

46.Zhang, L., Li, Z. \& Azamat, B., 2012. A Study of University Students' On-line Shopping Behavior Traits and Influencing Factors. In 2012 Fifth International Conference on Business Intelligence and Financial Engineering. pp. 649-652.

47.Zhang, Y. et al., 2011. Repurchase intention in B2C e-commerce - A relationship quality perspective. Information and Management, 48(6), pp.192-200. 